Francesca Fornari

Uniwersytet Ca’ Foscari Venezia

\title{
O brulionach wiersza Pan Cogito i wyobraźnia
}

\section{On the Drafts of the Poem Mr Cogito and the Imagination}

\begin{abstract}
The article subjects to analysis the selected motifs of the Zbigniew Herbert's poem $\mathrm{Mr}$ Cogito and the Imagination based on the draft copies of the work stored in the poet's archive. The analysis of the manuscripts, which reveals a different, hidden aspect of the final text, allows to investigate what was omitted in the process of creation, e.g. the motif of Daedal and the reference to the Upanishads, and trace the development of the significant themes of the poem: a concept of identity and the notion of tautology.
\end{abstract}

Keywords: Zbigniew Herbert, drafts, $M r$ Cogito and the Imagination, tautology

Streszczenie: W artykule analizowane są wybrane wątki wiersza Zbigniewa Herberta Pan Cogito $i$ wyobraźnia na tle brulionów tego utworu znajdujących się w archiwum poety. W analizie rękopisów, które odsłaniają inną, ukrytą stronę tekstu ostatecznego, można badać to, co zostało opuszczone w trakcie tworzenia, na przykład wątek Dedala i odwołanie do Upaniszad, oraz śledzić rozwój ważnych motywów wiersza - koncepcję tożsamości i pojęcie tautologii.

Słowa kluczowe: Zbigniew Herbert, bruliony, Pan Cogito i wyobraźnia, tautologia

Skupię się na analizie wybranych wątków wiersza Pana Cogito i wyobraźnia w świetle brulionów znajdujących się w archiwum poety, przedstawiających wersje robocze, które wiodły do ostatecznej postaci utworu. Interpretacja brulionów dossier genetycznego, składającego się z trzech rękopisów i z jednego maszynopisu, będzie selektywna, wezmę pod uwagę zarówno te elementy tekstu, które pojawiły się już w pierwszym brulionie, jak i te, które poddane były różnym zmianom podczas pisania, oraz to, co zostało całkowicie usunięte.

\section{Tautologia i metamorfozy}

W pierwszej redakcji pojawia się już dystych, który otworzy wersję ostateczną początek wiersza pozostanie niezmieniony: 
Pan Cogito nigdy nie ufał sztuczkom wyobraźni

nie kochał hybryd labiryntów sfinks napawał go odrazą ${ }^{1}$. fortepian na szczycie Alp

nie grał mu żadnych koncertów

fałszywe

Pan Cogito „nie kochał hybryd” - wyraz „hybryd” zostanie skreślony, i już nie wróci. Słowo usunięte przyciąga uwagę, staje się słowem potencjalnie ważnym, czasem wzbogacającym interpretację, i tworzy niekiedy dodatkowe sensy w zestawieniu z ostateczną wersją tekstu. Mitologicznym hybrydom Herbert okazywał niejeden raz współczucie, rehabilitując Minotaura, wzruszając się męką Marsjasza - ale są różne rodzaje hybryd... Znaczące jest, że negatywnie nacechowane słowo „hybryda” pojawia się także w jednym z brulionów Potęgi smaku, jako składnik „dialektyki oprawców”:

nigdy nie lubiliśmy hybryd - mowy

tautologii oxymoronu w retoryce ${ }^{2}$.

$\mathrm{Na}$ początku procesu tworzenia wiersza o wyobraźni i współczuciu nasunęła się więc Herbertowi myśl o hybrydach, jakby wprowadzająca wątek, co będzie także sednem wiersza - który dotyczy nie tylko wyobraźni i poetyki, ale także tożsamości i postawy etycznej, sposobu bycia artystą i człowiekiem. Współczucie jest ściśle związane z poczuciem tożsamości, jak podkreśla badacz Antonio Prete we wstępie do sugestywnej historii współczucia: wobec cierpienia drugiego człowieka współczujący podmiot odkrywa przepaść istniejącą między nim a bliźnim, a tym samym odkrywa niemoc własnego bytu pojedynczego. Współczucie jest więc „sprawą osobistą podmiotu”, gdyż nasza relacja do drugiego okazuje się wyznacznikiem naszego stosunku do świata ${ }^{3}$. I tylko ten współczujący stosunek do świata tu się liczy, więc Panu Cogito nie zależy na wizerunku kreowanym przez krytyków - jeśli chodzi o siebie jako artystę, Cogito zostaje wierny nakazowi współczucia za cenę powierzchownego zaklasyfikowania do "gatunku minores”.

Pierwsza redakcja jest mniej spójna, na marginesie kartki autor dodawał nowe fragmenty tekstu, notował myśli mogące służyć jako „natchnienie”, do zaawansowania w procesie tworzenia tekstu. Na prawym marginesie pierwszy prosty dopisek dotyczy tautologii:

tautologia tautologia

tożsamość

idem per idem ${ }^{4}$.

1 Archiwum Zbigniewa Herberta, Akc. 17 846, t. 1, s. 72.

2 Tamże, s. 292.

3 A. Prete, Compassione. Storia di un sentimento, Torino 2013, s. 17, 130-131.

${ }^{4}$ Archiwum Zbigniewa Herberta, Akc. 17 846, t. 1, s. 72. 
Nigdy nie wejdziemy na terytoria wyobraźni, możemy się jednak domyślać, że - być może - myśl o tautologii nasunęła autorowi refleksję na temat „niemoralności” metamorfoz, która zostanie tak rozwinięta w drugiej redakcjis:

metamorfozy

wydawały mu się

niemoralną ucieczką ${ }^{6}$.

Dlaczego następuje tu takie zdecydowane odrzucenie metamorfoz, które stanowią przecież literacką reprezentację maksymalnego zbliżenia się do drugiego? Metamorfozy są obrazem cielesnego przeżywania empatii, prowadzą do głębokiego odczuwania emocji bliźniego, do utożsamienia się z innym istnieniem, a utrata własnej tożsamości, formy i języka podczas metamorfoz może pobudzić wyobraźnię i współczucie przez silne zidentyfikowanie się z cierpią$\mathrm{cym}^{7}$. Wiersz Pan od przyrody, dedykowany profesorowi zabitemu przez „łobuzów od historii”, jest przecież także delikatnym marzeniem o niemożliwej metamorfozie ocalającej, o powrocie profesora na ziemię pod postacią żuka. I mitologia, często inspirująca Herberta, to płaszczyzna nieustannych przeobrażeń cielesnych bohaterów; tak jak poezja jest polem metafor, które przekształcają rzeczywistość - więc tu odrzucanie metafor, „dżungli skłębionych obrazów”, mogłoby być równoznaczne z odrzuceniem przemian negatywnie nacechowanych. Może jednak Herbert, kiedy pisał ten wiersz, nie tylko miał na myśli mitologiczne czy literackie przekształcenia, ale także szukał formuły, w której mieściłoby się prawdziwsze współczucie, mniej literackie, mniej fikcyjne i bardziej szczere. Opowiadałby się za modelem tożsamości, który byłby na przykład zaprzeczeniem negatywnego wizerunku przedstawionego w wierszu Chodasiewicz:

(...) ale jaka była jego entelechia

odpowiemy był hybrydą w której wszystko się telepie

duch i ciało góra z dołem raz marksista raz katolik

chłop i baba a w dodatku pół Rosjanin a pół Polak

(...)

sam nie wiedział kim był (...) (s. 617) ${ }^{8}$.

5 Tamże, s. 71.

6 Tamże.

7 Zob. A. Prete, dz. cyt., s. 78-86.

8 Podobną krytykę wyraził Herbert mocnym językiem publicystyki w wywiadzie „Pojedynki Pana Cogito”, podczas którego mówił o „proteuszowym” Miłoszu, któremu brak tożsamości. O konflikcie Herberta z Czesławem Miłoszem pisze Dagmara Zawistowska-Toczek w podsumowującym głosy na ten temat rozdziale Pojedynek wieszczów. Konflikt z Czestawem Mitoszem [w:] tejże, Stary poeta. „Ars moriendi” w późnej twórczości Zbigniewa Herberta, Lublin 2008, 
Obok trzech wersów o niemoralności metamorfoz występują w pierwszym brulionie dwie linijki, które wrócą w następnej redakcji - to określenie dotyczące Pana Cogito:

był jednym z wielu

ale tylko sobą?.

Zdania dotyczące tożsamości Pana Cogito wyrażają myśl tautologiczną: był, i chciał być - zapisuje dalej Herbert na tym samym brulionie - „tylko samym sobą”, więc wierny sobie, autentyczny... Pan Cogito będzie „uwielbiał tautologie” - ale poeta jest świadomy różnych odcieni i funkcji „tłumaczenia/ idem per idem". Tautologia jest podawana zwykle jako model wyrazu pustego, zbędnego, ale wraz z tautologią wchodzi w grę pojęcie prawdy, będące jej wyznacznikiem i, powiedziałabym, jej niebezpieczeństwem: w logice matematycznej tautologia to wyraz prawdziwy ze względów czysto logicznych, bez odnoszenia się do okoliczności rzeczywistych ${ }^{10}$. Będąc zdaniami zawsze prawdziwymi w systemie języka, tautologie mogą nam odbierać niezależność, umysł krytyczny i służyć dyskursowi władzy. Tak jest w cytowanym już wierszu Potęga smaku:

Zaiste ich retoryka była aż nazbyt parciana

(Marek Tulliusz obracał się w grobie)

łańcuchy tautologii parę pojęć jak cepy

dialektyka oprawców żadnej dystynkcji w rozumowaniu

składnia pozbawiona urody koniunktywu (s. 523).

Herbert prezentuje tu tautologie w negatywnym ujęciu - dobrym komentarzem do tych wersów mogą być refleksje Rolanda Barthes'a, który w Mitologiach wspominał, że tautologia to sformułowanie autorytatywne, niepozwalające na krytykę, gdyż stawiające przed rzeczywistością pozornie oczywistą, którą można tylko biernie akceptować. Dla Barthes'a tautologia jest agresywna, cudowną pewnością nicości, która uwalnia z obowiązku samodzielnego myślenia: „signifie une rupture rageuse entre l'intelligence et son objet, la menace arrogante d'un ordre où l'on ne penserait pas" ${ }^{11}$. Barthes podkreśla także drugi aspekt tautologii, która może być zdrową afazją, kiedy nic nam nie mówi, ale reprezentuje

s. 175-202. Wiersze Zbigniewa Herberta, jeśli nie podano inaczej, cytowane według wydania Wierszy zebranych, oprac. R. Krynicki, Kraków 2008.

9 Archiwum Zbigniewa Herberta, Akc. 17 846, t. 1, s. 72.

10 Dizionario di filosofia, Treccani, http://www.treccani.it/enciclopedia/tautologia_(Dizionario-di-filosofia)/, dostęp: 5.12.2017.

${ }^{11}$ R. Barthes, Racine est Racine, Le mythe, aujourd'hui [w:] tegoż, Mythologies, Paris 1957, s. 91. Tłumaczenie: „oznacza ona brutalne oderwanie myśli od jej przedmiotu, aroganckie groźby ze strony porządku, gdzie myśleć nie należy”. Tenże, Racine to Racine [w:] tegoż, Mitologie, tłum. A. Dziadek, Warszawa 2008, s. 129. 
prawa rzeczywistości wobec języka, i jest wyrazem głębokiego rozczarowania wobec mowy - wtedy tautologią zabijamy język, gdyż język nas zdradza ${ }^{12}$.

Właśnie dlatego, że ma związek z prawdą, tautologia jest niebezpieczna, trzeba posługiwać się nią ostrożnie. I może jest właśnie to, co chce nam powiedzieć Herbert, pisząc o grubiańskich tautologiach władzy w Potędze smaku, ale i też o „mądrych tautologiach” natury w Modlitwie Pana Cogito-podróżnika ${ }^{13}$ Zestawienie tych wierszy uświadamia nam, że tautologia może być hołdem stawianym rzeczywistości, ale może być także opatrzona znakiem ujemnym, jako niebezpieczne narzędzie manipulacji językowej i propagandy kłamliwej, której można ewentualnie tylko przeciwstawić inną tautologię, odsyłającą do twardej przestrzeni przedmiotów i faktów, do etyki, i powiedzieć jasno, że „niewola” jest „niewolą”.

Tautologia, którą „zabijamy język”, jest w sposób oczywisty związana z problemem przedstawiania rzeczywistości i może wyrażać euforyczny podziw dla istnienia i dla różnych form bytu, które język może próbować oddać tylko przez bezsilne powtórzenie - w tym sensie może być zinterpretowana jako „antymetafora" ${ }^{14}$, środek ekstremalnego realizmu, i dlatego też pojawia się w wierszu o wyobraźni ja lirycznego, który nie lubił koncertów na szczycie Alp. Warto tu wspomnieć słowa Umberto Eco, które mogą współgrać z realizmem Herberta. Biorąc udział w filozoficznej debacie nad pojęciem realizmu, odbywającej się we Włoszech w ostatnich latach, Eco mówił o „realizmie negatywnym”, o świadomości, że istnieje twarde sedno rzeczywistości: fakty często buntują się przeciw naszej interpretacji i wtedy zdajemy sobie sprawę, że nie możemy powiedzieć wszystkiego, że niektóre zdania będą fałszywe, że istnieją chwile, „kiedy świat, wobec naszych interpretacji, mówi nam NIE”15. I to „nie” - jak Herbertowski kamyk, który nie daje się oswoić - to opór stawiany przez ,jedyną" rzeczywistość wobec naszego języka i naszej wiedzy, i to jest wielka lekcja pokory. Stąd też zamiłowanie do tautologii, wyrażającej czasem euforyczny zachwyt dla świata, czasem jasną świadomość, że „niewola niewolą”. Zastanawiające, że w drugim brulionie krótka

12 Tenże, Racine est Racine, Le mythe, aujourd'hui [w:] tegoż, Mythologies, Paris 1957, s. 9192, 226-227.

${ }^{13} \mathrm{Na}$ temat tautologii w poezji Herberta zob. wnikliwy esej Wojciecha Ligęzy, Sen kamienia, tautologie natury [w:] Dialog i spór. Zbigniew Herbert a inni poeci i eseiści, red. J.M. Ruszar, Lublin 2006, s. 145-165; artykuł Dariusza Pawelca Elegia [w:] Niepewna jasność tekstu. Szkice o twórczości Zbigniewa Herberta 1998-2008, red. J.M. Ruszar, Kraków 2009, s. 129-145; monografię Magdaleny Śniedziewskiej Wierność rzeczywistości. Zbigniew Herbert o postawie wobec swiata i problemach jego reprezentacji, Kraków 2013.

${ }^{14}$ F. Muzzioli, Le strategie del testo. Introduzione all'analisi retorica della letteratura, Roma 2006 [2004], s. 116-117.

15 Por. „esiste uno zoccolo duro dell'essere, tale che alcune cose che diciamo su di esso non possano e non debbano essere prese per buone. (...) Ci sono delle cose che non si possono dire. Ci sono dei momenti in cui il mondo, di fronte alle nostre interpretazioni, ci dice NO", U. Eco, Di un realismo negativo [w:] tegoż, Bentornata realtà. Il nuovo realismo in discussione, red. M. De Caro, M. Ferraris, Torino 2012 [tłum. - F.F.]. 
sekwencja tautologii składała się wyłącznie z elementów odsyłających do sytuacji zagrożenia i utraty wolności, pierwszy wyraz nie odnosił się więc do świata natury, nie był to „ptak” wersji ostatecznej, ale narzędzie uwięzienia:

\author{
łańcuch jest łańcuchem \\ niewola niewolą \\ nóż jest nożem \\ śmierć śmierciąa ${ }^{16}$.
}

Jakby Herbert chciał podkreślić, że wobec zła można czasem tylko powtarzać prostą wiedzę tautologiczną, która okazuje się najmniej kłamliwa, gdyż nie fałszuje tej rzeczywistości, przeciw której możemy się buntować właśnie tylko wówczas, kiedy ją nazwiemy jasno po imieniu.

\title{
Dedal czy Ikar?
}

Trzeci z fragmentów dopisanych w środkowej kolumnie w pierwszej redakcji jest zalążkiem strofy, która wejdzie do ostatecznej wersji:

Pan Cogito

wznosił się rzadko

na skrzydłach metafory

xx i jak Dedal padał mocno

na twarz ziemi ${ }^{17}$.

Fragment zostanie poddany lekkim zmianom w drugiej i trzeciej redakcji, ale zawsze pojawia się wzmianka o Dedalu. Tylko w zachowanym maszynopi$s i e^{18}$, który stanowi ostatni etap procesu genezy tekstu, ta strofa już się nie różni od wersji drukowanej, gdzie mitologiczna postać, do której porównuje się Pana Cogito, to już nie Dedal, lecz Ikar:

unosił się rzadko na skrzydłach metafory potem spadał jak Ikar w objęcia Wielkiej Matki

\footnotetext{
16 Archiwum Zbigniewa Herberta, Akc. 17 846, t. 1, s. 71.

17 Tamże, s. 72.

${ }^{18}$ Archiwum Zbigniewa Herberta, Akc. 17 846, t. 2, s. 81.
} 
Myśl o Dedalu jako modelu postawy Pana Cogito wobec metaforycznych lotów sztuki nasunęła się jako pierwsza i wracała w kolejnych redakcjach. Nie byłoby to pierwsze pojawienie się Dedala w poezji Herberta, który uruchomił własną „wyobraźnię mitologiczną”, by przedstawić, w Dedalu i Ikarze, dialog między ojcem i synem przed mitycznym lotem. Dedal udziela Ikarowi rady, patrząc $w$ niebo, ma on pamiętać, że idzie, a nie lata, lecz oczy syna „jak dwa kamenie” wpatrzone są w ziemię. Ikar Herberta spadnie do morza, gdyż za mocno czuł przyciąganie ziemi. Końcowy komentarz zdaje się podkreślać niemoc i naiwność Ikara, natomiast Dedal wydaje się człowiekiem świadomym ludzkiej kondycji bycia między niebem a ziemią - to on wspomina, że skrzydła są tylko ozdobą, że można się wznieść tylko tyle, ile jest nam dane. W Ojcach gwiazdy temat życia zgodnego z prawami natury wiąże się właśnie z postacią Dedala, naukowca i mędrca zdolnego rozumieć, że nie wolno przekraczać ludzkich granic ${ }^{19}$. W Historii Minotaura Dedal występuje jeszcze jako twórca architektury pedagogicznej, który projektuje labirynt - więzienie nieszczęsnego Minotaura. Labiryntów nie lubił Pan Cogito w tym wierszu, być może dlatego Herbert zdecyduje się na usunięcie Dedala, który zresztą chyba nie „spadł mocno” na ziemię, gdyż szcześliwie zakończył swój lot.

Analizując mit literacki Dedala, André Peyronie wspomina, że w XX wieku Dedal ustępuje często miejsca Ikarowi, jako postać człowieka zdolnego latać, ale zostaje także „zrehabilitowany” w swojej roli architekta i wynalazcy, stając się ważnym punktem odniesienia w literaturze współczesnej. Występuje w niej jako archetyp artysty budującego dzieła sztuki, które są labiryntami ze słów - na przykład w Portrecie Jamesa Joyce’a, w Stoffe Friedricha Dürrenmatta. Jako artysta świadomy swoich możliwości Dedal uosabia racjonalny czynnik twórczości artystycznej w opozycji do czynnika heroicznego, reprezentowanego w micie przez Ikara ${ }^{20}$. Przejście od Dedala do Ikara może lepiej odpowiada ironicznej deprecjacji Pana Cogito jako artysty z „gatunku minores", i przede wszystkim potęguje dramatyzm postawy Pana Cogito, jego wierność ziemi, nawet za cenę utraty życia - tak jak zdarzyło się Ikarowi.

\section{Pan Cogito chciał pojąć do końca}

$\mathrm{Na}$ kartkach brulionów możemy obserwować tworzenie się słynnego wyliczenia dotyczącego tematów sztuki wyobraźni i współczucia Pana Cogito. Enumeracja jawi się jako uporządkowana, ponieważ poddana jednej

19 Ojcowie gwiazdy: „dzieciom będą czytali bajkę o Dedalu/ miał rację Grek księżyca nie chciał ani gwiazdy/ był tylko ptakiem został w porządku natury/ a rzeczy które tworzył szły za nim jak zwierzęta/ i jak płaszcz nosił na plecach swe skrzydła i los" (s. 278).

20 A. Peyronie, „Dedalo” [w:] Dizionario dei miti letterari, red. P. Brunel [red. włoskiego wydania G. Gabetta], Milano 1995, s. 169-176. 
zasadniczej myśli, składa się bowiem z tego, co Pan Cogito chciał „pojąć do końca”. Jest także zamknięta, gdyż zakończona składnikami, które streszczają i kondensują wspólny los elementów całej enumeracji, los „wzrostu i upadku" natury i kultury. Wyliczenie jest tu więc wyrazem ja autorskiego, który oznacza kierunek interpretacji ${ }^{21}$.

W kolejnych redakcjach następuje wahanie co do czasownika, który otwiera enumerację i miałby oddać cel formuły sztuki jako współczucia, Herbert notuje na przemian: „wczuć się w”, „zrozumieć” i „pojąć”. W ostatnim brulionie sąsiadują jeszcze ze sobą dwie alternatywy, zanim Herbert zapisze na prawej stronie kartki ostateczną opcję, wers o rytmie trocheicznym: Pan Cogito „pragnął pojąć do końca”. Najbardziej znaczące wydaje się skreślenie z substytucją w pierwszej redakcji, gdzie następuje wybór, który wyraża zdystansowanie się wobec pierwszego odruchu empatii: zamiana czasownika „wczuć się" na mniej zabarwione uczuciowo i bardziej intelektualne „zrozumieć”, które w końcu zastąpione zostanie przez „pojąć”.

Przedstawię tu krótko listę elementów, które pojawiają się w kolejnych redakcjach. W pierwszej tak wygląda lista „przedmiotów ożywionych i nieożywionych”, które Pan Cogito chciał „zrozumieć”:
światło południa
upadek Sassanidów
wodospad górę
sny Marii Stuart
Martwe
pustynię|tak jakby był pustynią]
obrońców Masady
wzrost i upadek Rzymu
wzrost i upadek sekwoji dębu ${ }^{22}$.

Pierwszy element to światło, ważne słowo tej poezji, tradycyjny symbol mądrości, od którego dzieli nas według autora Epilogu burzy „wielka przepaść". Wrażliwość Herberta na światło występuje już we wspomnieniu dzieciństwa, do którego pisarz wracał niejeden raz w wywiadach, opowiadając, jak był zafascynowany murem naprzeciwko okna mieszkania we Lwowie, jak ten „mur z ciepłym światłem” stał się później abstrakcyjnym przeżyciem,

${ }^{21}$ Odwołuję się do rozważań Lea Spitzera o wyliczeniu w poezji współczesnej, tenże, L’enumerazione caotica nella poesia moderna [1961], „L'Asino d'oro”,1991, nr 3, s. 92-130. Witold Sadowski omawia typologię wyliczenia w poezji Herberta, przywołując enumerację w wierszu Pan Cogito i wyobraźnia jako przykład „pierwszego sposobu”, „potraktowania utworu jako kartki wyrwanej z notatnika”. Por. W. Sadowski, Śladem gatunków modlitewnych w poezji Herberta [w:] Między nami a świattem. Bóg i świat w twórczości Zbigniewa Herberta, red. G. Halkiewicz-Sojak, J.M. Ruszar, R. Sioma, Toruń-Kraków 2012, s. 253-254.

${ }^{22}$ Archiwum Zbigniewa Herberta, Akc. 17 846, t. 1, s. 72. 
„niewyrażalnym kolorem”, który go prześladował ${ }^{23}$. Upadek Sassanidów zostanie zastąpiony w drugiej redakcji przez „intrygi Sassanidów”, a w trzeciej redakcji zniknie - być może jedno imperium, rzymskie, było wystarczające w wierszu... Elementy pejzażu przyrody są tu elementami pionowymi, które mogą w liryce odsyłać do innego niż ziemski wymiaru, nie dziwi, że w drugiej redakcji, obok „wodospadu góry obłoku” Herbert dopisze także „ekstazy mistyków". W drugim brulionie nie będzie już śladu fragmentu wyrażającego bardziej bezpośrednio cechę empatii autora, która miała prowadzić do całkowitej identyfikacji: zrozumieć „pustynię [tak jakby był pustynią]”. W ostatniej redakcji znikną także obrońcy Masady, którzy mocno pobudzali „wyobraźnię historyczną" Herberta (o czym wiemy na przykład ze wspomnienia Davida Weinfelda o pobycie poety w Izraelu ${ }^{24}$ ).

W drugiej redakcji pojawią się nowe elementy, niektóre („natura diamentu”, „szaleństwa ludobójców”) wejdą do wersji ostatecznej, inne zostaną tylko na kartach brulionów, jak „dramat Jana Husa” i „ekstazy mistyków”. W trzeciej redakcji sąsiadują ze sobą dwie wersje wyliczenia, w lewej kolumnie przedostatnia, ze znaczącymi skreśleniami:

$\begin{array}{ll}\text { noc Pascala } & - \text { gniew Achillesa } \\ \text { melancholię proroków } & \text { noc Pascala } \\ \text { szaleństwa ludobójców } & \text { melancholię proroków } \\ \text { sny }{ }_{\mathrm{m}} \text { Marii Stuart } & \text { gniew Achillesa } \\ \text { strach Aleksandra neandertalski } & \text { szaleństwa ludobójców } \\ \text { konanie Kleopatry długie konanie Ni t schego } & \text { sny Marii Stuart } \\ \text { marzenia prostych ludzi } & \text { strach neandertalski } \\ & \text { rozpacz ostatnich Azteków } \\ & \text { długie konanie niczego Nietzschego } \\ & \text { wzrost i upadek dębu radość malarza z Lascaux } \\ & \text { wzrost i upadek Rzymu }{ }^{25} .\end{array}$

Strach Aleksandra, bohatera historii i apokryfu Herberta Węzet gordyjski, który wobec „splątanej materii świata” nie umiał akceptować „cudownej ludzkiej niepewności”, zastąpiony zostanie strachem ludzkości neandertalskiej Herbert cofa się w głąb naszej historii prekulturowej, przechodzi do przeszłości człowieka prymitywnego. Kleopatra zamieniona zostanie na ważnego dla Herberta Friedricha Nietzschego. Myśliciel, który patrzył bezlitośnie na słaby podmiot współczujący, staje się tu przedmiotem czułości Pana Cogito, który

${ }^{23}$ Z. Herbert, Światto na murze. Rozmawia Marek Sottysik [w:] Herbert nieznany. Rozmowy, Warszawa 2008, s. 112-113.

${ }_{24}$ Zob. D. Weinfeld, Rozproszone wspomnienia o Herbercie $w$ Izraelu, http://www.fundacjaherberta.com/krotki-rys-biograficzny/wspomnienia-rodziny-i-przyjaciol-o-herbercie/david-weinfeld, dostęp: 26.04.2017.

${ }^{25}$ Archiwum Zbigniewa Herberta, Akc. 17 846, t. 1, s. 73. 
chciałby zrozumieć to, co wydaje się niemożliwe do zrozumienia - ciemne cierpienie filozofa, zaciętego wroga współczucia, który tym bardziej wzbudza naszą ludzką litośćć ${ }^{26}$. Znaczący w trzeciej redakcji wyliczenia jest ostatni element, „marzenia prostych ludzi”, które zamykałyby listę, przeciwstawiając się światopoglądowi filozofa nadczłowieka. Ostatnia, czwarta wersja wyliczenia jest już bliska ostatecznej, Herbert wahał się jeszcze, czy dodać „naturę diamentu", końcowa wersja enumeracji zawiera mniej elementów przyrody, a więcej ludzkiego cierpienia i doświadczeń granicznych, oprócz jednej nuty całkowicie jasnej, obecnej tylko dzięki dopisaniu „radości malarza z Lascaux”.

\section{Wierzyl naiwniel w jedna rzeczywistość}

Zagadnienie realizmu i stosunku Herberta do rzeczywistości zajmowało i będzie dalej zajmować badaczy jego poezji; to wielki temat tej twórczości, do zinterpretowania zarówno w kategoriach historii kultury - w odwołaniu na przykład do dyskusji na temat wyobraźni i realizmu w Polsce w latach pięćdziesiątych jak i w filozofii czy estetyki. Na stronach brulionów omawianego wiersza powtarza się słowo „rzeczywistość” - obecne już w czwartej strofie pierwszej redakcji, to słowo wróci potem na prawym marginesie dolnym, wśród zapisów tekstu in fieri, notujących czasem ważne myśli, które wejdą później do wiersza. Te dwa wersy o Panu Cogito tak brzmią:

wierzył naiwnie

w jedną rzeczywistość ${ }^{27}$.

W drugiej redakcji strofa ta znajduje się w pozycji końcowej i tłumaczy, dlaczego w wyobraźni Cogito „nie ma miejsca/ na sztuczne ognie poezji”: „bowiem uwierzył naiwnie/ w jedyną rzeczywistość". W pierwszej i drugiej redakcji pojawia się ciekawy motyw indyjski, który miał potwierdzić wiarę w istnienie tej jednej rzeczywistości. Z wszystkich „zdań mądrości”, pisze Herbert, Cogito:

najbardziej lubit

to jesteś ty

niewidzialna substancjo

pestko figi ${ }^{28}$.

"Pestko figi” odsyła nas do szóstego rozdziału Upaniszad Chandogya, do dialogu ojca z synem Svetateku, który po dwunastu latach studiowania

${ }^{26}$ O nietzscheańskiej krytyce współczucia pisze A. Prete, dz. cyt., s. 128-130.

27 Archiwum Zbigniewa Herberta, Akc. 17 846, t. 1, s. 72.

28 Tamże, s. 72. 
u mistrza wrócił do domu, w wieku 24 lat, przekonany, że jest już mędrcem. W dwunastym podrozdziale ojciec namawia syna, by obrał owoc indyjskiej figi aż do pestki, i poucza go, że w tej otwartej pestce zawarty jest wszechświat, że ta pestka to on: „to jesteś ty, o Svetateku”29.

Na marginesie Herbert zapisał też: „Tat tvam asi”. Są to „wielkie słowa” formuły mądrości Upaniszad, które znaczą: „Ty, duszo pojedyncza, jesteś Tat”, bytem, pierwiastkiem najwyższym. To zdanie wyraża identyfikację między Brahman i Atman, między tym, co najmniejsze, a tym, co największe, oraz wiarę, że pod wszelkimi zjawiskami kryje się „jedna rzeczywistość” ${ }^{30}$. Do Atman-Brahman można dojść, odrywając się od rzeczywistości ziemskiej, jednak - jak pisze badacz Carlo della Casa - wydaje się, że Upaniszady nie głoszą kompletnego oderwania się od świata - jeśli wszelkie zjawiska, będąc częścią Jednego, zawierają w sobie prawdę, to trzeba akceptować życie ziemskie: „człowiek jest zakotwiczony na ziemi i nie może abstrahować od doświadczeń własnej kondycji: stąd wynika ludzkość Upaniszad"31.

Fragment wypowiadający jasno, że „sztuczne ognie” wyobraźni są odrzucane w imię „jednej rzeczywistości”, zniknie, jak zniknie motyw indyjski, który pojawi się jeszcze w drugiej redakcji-odwołanie do Upaniszad i do „tat tvam asi”, bezcienia ironii, pasowało do przesłania wiersza, lecz może wiodłoby czytelnika tekstu, który jest mocno po stronie konkretu i ludzkiego cierpienia, w inne, mistyczne strony.

\section{Swej niepewnej jasności}

Zakończę, cytując ostatnie zdanie wiersza, które pojawia się już w pierwszym brulionie. Pan Cogito:

chciał pozostać wierny

swej ciemnej jasności ${ }^{32}$.

W drugim rękopisie współistnieją dwie jego redakcje, w postaci nierozstrzygniętych alternatyw, autor jeszcze się waha, Pan Cogito:

chciałby pozostać wierny

swej ciemnej jasności niepewnej jasności ${ }^{33}$.

${ }^{29}$ Upaniszad Chandogya [w:] Upanisad, red. C. della Casa, Classici delle religioni, Torino 1983 , s. 250 [tłum. - F.F.].

${ }^{30}$ Upanisad, dz. cyt., s. 20.

31 C. della Casa, Wprowadzenie [w:] Upanisad, dz. cyt., s. 23-24 [tłum. - F.F.].

32 Archiwum Zbigniewa Herberta, Akc. 17 846, t. 1, s. 72.

33 Tamże, s. 71. 
W ostatnim brulionie decyzja zapadła, pozostaje jeden znak wahania, widoczne jest skreślenie małego słówka, zaimka dzierżawczego. Pan Cogito:

chciałby pozostać wierny

swej niepewnej jasności ${ }^{34}$.

„Ciemna jasność” Pana Cogito staje się już na zawsze „niepewna”, Herbert wybiera oksymoron nieco mniej metaforyczny, przez substytucję „ciemności” z „niepewnością, która bardziej konkretnie określa wiedzę, do jakiej dąży Pan Cogito, a poprzez eliminację zaimka dzierżawczego ta „niepewna jasność” nie jest już tylko prywatną perspektywą Pana Cogito, lecz staje się formułą ogólniejszej poetyckiej, filozoficznej i egzystencjalnej wizji, także, być może, naszej. I ta jasność będzie zawsze niepewna, gdyż w niej ma być miejsce na cierpienie drugiego i na świadomość, że zarówno wobec tego cierpienia, jak i wobec nagiej prawdy rzeczywistości nasza wiedza oraz nasza wyobraźnia są zawsze ograniczone, a czasem okazują się tylko tautologiczną powtórką.

\section{Bibliografia}

Barthes R., Mythologies, Paris 1957.

Della Casa C., Wprowadzenie [w:] Upanisad, red. C. della Casa, Classici delle religioni, Torino 1983.

Dizionario di filosofia, Treccani, http:/www.treccani.it/enciclopedia/tautologia_ (Dizionario-di-filosofia)/, dostęp: 5.12.2017.

Eco U., Di un realismo negativo [w:] tegoż, Bentornata realtà. Il nuovo realismo in discussione, red. M. De Caro, M. Ferraris, Torino 2012.

Herbert Z., Światto na murze. Rozmawia Marek Sottysik [w:] Herbert nieznany. Rozmowy, Warszawa 2008.

Herbert Z., Wiersze zebrane, oprac. R. Krynicki, Kraków 2008.

Ligęza W., Sen kamienia, tautologie natury [w:] Dialog i spór. Zbigniew Herbert a inni poeci i eseiści, red. J.M. Ruszar, Lublin 2006.

Muzzioli F., Le strategie del testo. Introduzione all'analisi retorica della letteratura, Roma 2006 [2004].

Pawelec D., Elegia [w:] Niepewna jasność tekstu. Szkice o twórczości Zbigniewa Herberta 1998-2008, red. J.M. Ruszar, Kraków 2009.

Peyronie A., Dedalo [w:] Dizionario dei miti letterari, red. P. Brunel [red. włoskiego wyd. G. Gabetta], Milano 1995.

Prete A., Compassione. Storia di un sentimento, Torino 2013.

34 Tamże, s. 73. 
Sadowski W., Śladem gatunków modlitewnych w poezji Herberta [w:] Między nami a świattem. Bóg $i$ świat w twórczości Zbigniewa Herberta, red. G. Halkiewicz-Sojak, J.M.Ruszar, R. Sioma, Toruń-Kraków 2012.

Spitzer L., L'enumerazione caotica nella poesia moderna [1961], „L'Asino d'oro” 1991, nr 3.

Śniedziewska M., Wierność rzeczywistości. Zbigniew Herbert o postawie wobec świata i problemach jego reprezentacji, Kraków 2013.

Upaniszad Chandogya [w:] Upanisad, red. C. della Casa, Classici delle religioni, Torino 1983.

Weinfeld D., Rozproszone wspomnienia o Herbercie w Izraelu, http://www.fundacjaherberta.com/krotki-rys-biograficzny/wspomnienia-rodziny-i-przyjaciol-o-herbercie/david-weinfeld, dostęp: 26.04.2017.

Zawistowska-Toczek D., Stary poeta. „Ars moriendi” w późnej twórczości Zbigniewa Herberta, Lublin 2008. 